\title{
環状モノテルペノイドの生合成一一鎖状アリルニリン酸の 環化における二価金属イオンの役割122)
}

（1987 年 8 月 20 日受理）

\author{
菅 隆 幸*・泉 俊輔・平賀良知
}

\begin{abstract}
鎖状アリル二リン酸が環化して，環状モノテルペノイドを生成するさいの二価金属イオンの役割と反 応機構を調べた。鎖状アリル二リン酸が環化し，環状モノテルペノイドが生成するさいには（i）配 位能の高い二価金属イオンのリナリル二リン酸への作用が不可欠であること，（ii）このさいに二価金 属イオンは二リン酸部分とキレート配位すること，および（iii）この配位の形成によって C-O 結合が 弱められ，エネルギー的にもっとも環化反応をらけやすい構造のリナリルカチオンが発生しやすくなる ことが明らかになった。
\end{abstract}

\section{1 緒一言}

テルペノイド類は, 自然界に広く存在し，その基本単位は $\mathrm{C}_{5}$ の“イソプレン単位”からなっている。とくに, 高等植物に広く 分布する環状モノテルペノイド類は, ジチルフリルニリン酸 （二リン酸エステル，以下二リン酸と略記する）にイソペンテニ ルニリン酸が縮合して生成する $\mathrm{C}_{10}-$ プレニル鎖が閉環・環化し て形成される。Ruzicka らは, 環状モノテルペノイド生合成の直 接の前䣥体はネリル二リン酸（以下 NPP と略記する）であるこ

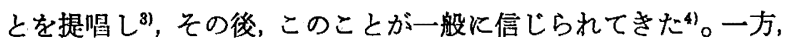
著者らは，リナリルニリン酸（以下 LPP と略記する）がゲラニ ルニリン酸 (以下 GPP と略記する) と NPP のシスートランス異 性化の仲立ちをしていること市とハッカ（Mentha spicata）およ びナッダイダイ (Citrus natsudaidai) の粗酵素系において GPP や NPP よりも LPP が環状モノテルペノイドへより多く取り込

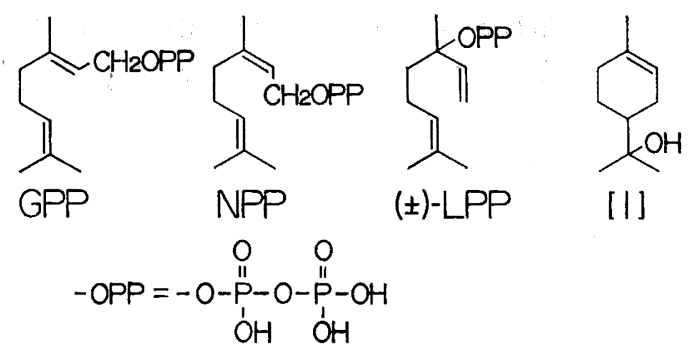

厷島大学理学部化学教室, 730 広島市中区東千田町

1）この報文を “The Biosynthesis of Isoprenoids in Higher Plants”の（第 5 報）とする.

2）前報（第 4 報）， T. Suga， S. Ohta， T. Ohmoto，J. Chem. Soc., Perkin Trans. 1, 1987, 2845.

3) L. Ruzicka, A. Eschenmosre, H. Heusser, Experientia, 9, 357(1953).

4) D. V. Banthorpe, P. N. Christou, C. R. Pink, D. G. Watson, Phytochemistry, 22, 2465(1983).
まれるこど(8)を見いだしこれらのことから，LPP が環状モノテ ルペノイド生合成のより直接の前駆体である可能性を示唆した7)。 他方, GPP p NPP は, その粗酵素系に共存する酸性ホスファ ターゼによってLPPよりも速く加水分解されること采と，部分精 製した酵素によるこれら鎖状アリルニリン酸類の環化過程には, $\mathrm{Mn}^{2+}$ あるいは $\mathrm{Mg}^{2+}$ などの二価金属イオンが必須の因子であ ることを見いだした778)。

そこで，環状モノテルペノイド生合成過程における二価金属イ オンの役割を明らかにするために，鎖状アリル二リン酸に二価金 属イオンのみを加えて反応生成物を調べた。さらに，鎖状アリル 二リン酸に二価金属イオンが配位する過程を, 常磁性二価金属イ オン添加にともなら鎖状アリルニリン酸の ${ }^{1} \mathrm{H}-\mathrm{NMR}$ スペクトル の変化から調べた。さらにまた，分子軌道法を用いて鎖状アリル 二リン酸と $\mathrm{Mn}^{2+}$ との配位中間体の棈造を解明すると同時に，鎖 状フリルニリン酸と $\mathrm{Mn}^{2+}$ との反応を紫外線吸収差スペクトル 法により追跡した。

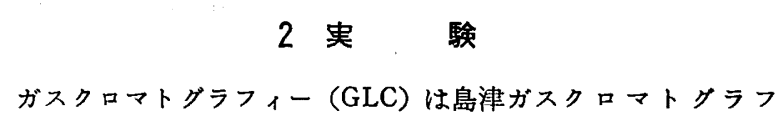
GC-6 A 型を使用し，カラムには 15\% DEGS および $2 \%$ OV-17 を用い， $2^{\circ} \mathrm{C} /$ 分で $40 \sim 150^{\circ} \mathrm{C}$ まで昇温することにより行なった。 GC-MS は島津ガスクロマトグラフ質量分析計 GCMS-QP 1000 型を用いて测定した。IR スペクトルは日本分光赤外分光光度計 A-102 型を用いて测定した。 ${ }^{1} \mathrm{H}-\mathrm{NMR}$ スペクトルは日立 Fourier 变換核磁気共鳴装置 $\mathrm{R}-600$ 型 $(60 \mathrm{MHz})$ を用い, 重水中,

5) T.Suga, T. Shishibori, H. Morinaka, J. Chem. Soc., Chem. Commun., 1980, 167.

6) T.Suga, T. Hirata, H. Okita, K. Tsuji, Chem. Lett., 1983, 1491.

7) T.Suga, T. Hirata, T. Aoki, T. Shishibori, Phytochemistry, 25, 2769(1986).

8）菅隆幸, 平田敏文, 泉 俊輔, 平賀良知, 浅野要一, 第 29 回天然有機化合物討論会要旨集, p.185 (1987). 
TSP を内部標準として測定した。また，紫外線吸収差スペクトル の測定には島津自記分光光度計 UV-240 型を用いた。

\section{1 鎖状アリルニリン酸類の合成}

\section{ゲラニルニリン酸 $(\mathbf{G P P})$}

ゲラニルニリン酸は、ゲラニオール $\left[n_{\mathrm{D}}{ }^{25} 1.4755, d_{4}{ }^{25} 0.8900\right.$ (lit $\left.\left.{ }^{9)} n_{\mathrm{D}}{ }^{25} 1.4766, d_{4}{ }^{25} 0.8894\right)\right]$ を $N-ク$ ロロスクシンイミドで 塩素化したのち, tris(tetrabutylammonium)hydrogen diphosphate でリン酸エステル化して調製した10)。これを，セルロース カラムクロマトグラフィー（溶媒：2-プロパノールーフセトニト リル $0.1 \mathrm{~mol} \cdot \mathrm{dm}^{-3}$ 炭酸水素アンモニウム $\left.2: 1: 1 \mathrm{v} / \mathrm{v}\right)$ で精製 したのち，溶出液を減圧下で濃縮後，飽和塩化りチウム溶液を添 加し，ついでアセトンを加えて結晶を析出させた。この結晶を沪 過後，3\% アンモ二ア水で溶解し，その溶液を凍結乾燥すること により GPP のリチウム塩を得た。収率 $40.0 \%$ 。白色粉末結晶。 IR $(\mathrm{KBr})\left(\mathrm{cm}^{-1}\right): 1206.7,1179.4(\mathrm{P}=\mathrm{O}), 956.0(\mathrm{P}-\mathrm{O}-\mathrm{P})$ ${ }^{1} \mathrm{H}-\mathrm{NMR}\left(\mathrm{D}_{2} \mathrm{O}\right) \delta: 5.41(2 \mathrm{H}, \mathrm{m}), 4.51(2 \mathrm{H}, \mathrm{m}), 2.11$ $\left(4 \mathrm{H}, \mathrm{m},-\mathrm{CH}_{2} \mathrm{CH}_{2}-\right), 1.72(6 \mathrm{H}, \mathrm{s}, 9-$ および 10-Me), 1.64 (3 $\mathrm{H}, \mathrm{s}, 8-\mathrm{Me})$ 。

\section{ネリルニリン酸 (NPP)}

ネリルニリン酸は，上記の GPP の合成と同じ方法に上う， ネロール $\left[\begin{array}{llll}n_{\mathrm{D}}{ }^{25} & 1.4700, & d_{4}{ }^{25} & 0.8815\end{array}\right.$ (lit $^{11)} n_{\mathrm{D}}{ }^{25} 1.4730, d_{4}{ }^{25}$ 0.8820)]をリン酸エステル化しこれに飽和塩化リチウム溶液 を加えてリチウム塩として得た。収率 $31.0 \%$ 。白色粉末結晶。

IR $(\mathrm{KBr})\left(\mathrm{cm}^{-1}\right): 1205.0,1180.0(\mathrm{P}=\mathrm{O}), 955.0$ (P-O-P) ${ }^{1} \mathrm{H}-\mathrm{NMR}\left(\mathrm{D}_{2} \mathrm{O}\right) \delta: 5.36(2 \mathrm{H}, \mathrm{m}), 4.47(2 \mathrm{H}, \mathrm{m}), 2.19$ $\left(4 \mathrm{H}, \mathrm{m},-\mathrm{CH}_{2} \mathrm{CH}_{2}-\right), 1.79(3 \mathrm{H}, \mathrm{s}, 9-\mathrm{Me}), 1.69(3 \mathrm{H}, \mathrm{s}$, $10-\mathrm{Me}), 1.64(3 \mathrm{H}, \mathrm{s}, 8-\mathrm{Me})$ 。

リナリルニリン酸 (LPP)

リナリルニリン酸は, (土)ーリナロオール $\left[n_{\mathrm{D}}{ }^{25} 1.4625, d_{4}{ }^{25}\right.$ $\left.0.8633\left(\mathrm{lit}^{12)} n_{\mathrm{D}}{ }^{25} 1.4621, d_{4}{ }^{25} 0.8650\right)\right]$ をジオキサン二リン酸 でリン酸エステル化して調製した ${ }^{13)}$ これをシリカゲルカラム クロマトグラフィー（溶媒：2-プロパノール-28\% アンモニア 水一水 $6: 3: 1 \mathrm{v} / \mathrm{v}$ ) で精製したのち，GPP の合成の場合と同じ方 法により，飽和塩化りチウム溶液を添加してリチウム塩とした。 収率 $6.4 \%$ 。白色粉末結晶。

IR $(\mathrm{KBr})\left(\mathrm{cm}^{-1}\right): 1206.7,1179.4(\mathrm{P}=\mathrm{O}), 956.0(\mathrm{P}-\mathrm{O}-\mathrm{P})$ ${ }^{1} \mathrm{H}-\mathrm{NMR}\left(\mathrm{D}_{2} \mathrm{O}\right) \delta: 6.15(1 \mathrm{H}, \mathrm{m}), 5.26(3 \mathrm{H}, \mathrm{m}), 1.86$ $\left(4 \mathrm{H}, \mathrm{m},-\mathrm{CH}_{2} \mathrm{CH}_{2}-\right), 1.69(3 \mathrm{H}, \mathrm{s}, 10-\mathrm{Me}), 1.64(3 \mathrm{H}, \mathrm{s}$, 8-Me), $1.57(3 \mathrm{H}, \mathrm{s}, 9-\mathrm{Me})$ 。

\section{2 鎖状アリルニリン酸類と二価金属イオンとの反応}

GPP，NPP および LPP のリチウム塩 $\left(8.0 \times 10^{-2} \mathrm{mmol}\right)$ をあ らかじめそれぞれ $2 \mathrm{ml}$ の $0.1 \mathrm{~mol} \cdot \mathrm{dm}^{-3} \mathrm{BES}$ 緩衝液 ${ }^{14)}(\mathrm{pH} \mathrm{7.0)}$ に溶解した。これらの溶液に塩化マンガン $(\mathrm{II})\left(\mathrm{MnCl}_{2} \cdot 4 \mathrm{H}_{2} \mathrm{O}\right)$ の

9) F. Tiemann, Ber., 26, 2708(1893).

10) V. Jo Davisson, A. B. Woodside, C. D. Poulter, Methods Enzymol., 110, 130(1985).

11) O. Zeitschel, Ber., 36, 265(1903).

12) G. Ohloff, E. Klein, Tetrahedron, 18, 37(1962).

13) G. Popjak, J.W. Cornforth, R. H. Cornforth, R. Ryhage, D.S. Goodman, J. Biol. Chem., 237, 56(1962).

14) N. E. Good, G. D. Winget, W. Winter, T. N. Connolly, S. Izawa, R. M. M. Singh, Biochemistry, 5, 467 (1966).
$0.1 \mathrm{~mol} \cdot \mathrm{dm}^{-3} \mathrm{BES}$ 緩衡液 $\left(1.8 \mathrm{mmol} \cdot \mathrm{dm}^{-3}\right)$ をそれぞれ $1 \mathrm{~m} l$ 加 えて, 全溶液中の $\mathrm{Mn}^{2+}$ 濃度が $0.6 \mathrm{mmol} \cdot \mathrm{dm}^{-3}$ になるようにし た。これを窒素雾团気下, $37^{\circ} \mathrm{C}$ で反応させた。その他の二価金属 イオンについても塩化物 $\left(\mathrm{MgCl}_{2}, \mathrm{CuCl}_{2}, \mathrm{FeCl}_{2} \cdot 6 \mathrm{H}_{2} \mathrm{O}\right)$ を用い, 同样な反応を行なった。反応開始後，一定時間ごとに反応溶液を $400 \mu l$ ずつ取りだし, $1 \mathrm{ml}$ のエーテルで 5 回抽出した。エーテル 層は, 皿水硫酸ナトリウムで踥燥ののち, 常圧蒸留により $500 \mu l$ まで浱縮した。これに窒素気流をゆるやかに吹きつけて $30 \mu l に$ まで濃縮した。濃縮後, マイクロシリンジで $2 \mu l$ を取り, GLC および GC-MS によって反応生成物の分析を行なった。

\section{3 分子軌道法計算}

本研究では通常の $\mathrm{CNDO} / 2$ 計算 155 によた。このさい, エネ ルギー項は一中心エネルギー項と二中心エネルギー項に分離し $た^{16)}$ 。分子構造の最適化は, 炭素鎖部分については MM 2 法 $^{17)}$ より行なった。リン酸基部分の座標は，X線結晶解析の結果から 得られたもの ${ }^{18)}$ をいた。

2.4 二価金属イオンの存在下における鎖状アリルニリン酸類 の ${ }^{1} \mathrm{H}-\mathrm{NMR}$ スペクトル

GPP, NPP および LPP のリチウム塩 $\left(1.2 \times 10^{-2} \mathrm{mmol}\right)$ をあ らかじめ $0.4 \mathrm{ml}$ の重水に溶解した。これらの溶液に二洒金属の 塩化物の重水溶液 $\left(5.4 \mathrm{mmol} \cdot \mathrm{dm}^{-3}\right)$ をそれぞれ $50 \mu l$ 加卉, 全 溶液中の二洒金属イオン濃度が $0.6 \mathrm{mmol} \cdot \mathrm{dm}^{-3}$ になるよらにし た。この二価金属イオンを添加する前と添加 1 分後のスペクトル

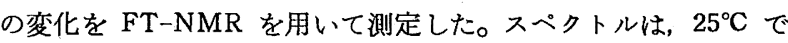
spectral width $600 \mathrm{~Hz}$, data point $4 \mathrm{k}$ とし，5秒間隔で 6 回 の積算により得た。

\section{5 紫外線吸収差スペクトル}

周囲に恒温水を循環できるセルホールダーに, 同一の光路長を もつ 4 個のセル $(1 \times 1 \times 3 \mathrm{~cm})$ をそれぞれ対照側, 試料側に 2 個 ずつおいた。対照セルと試料セルのそれぞれの1個に, GPP, NPP および LPP のリチウム塩 $\left(0.4 \mathrm{mmol} \cdot \mathrm{dm}^{-3}\right)$ を $6 \mathrm{ml}$ の水 に溶解した溶液 $3 \mathrm{~m} l$ ずつを入れた。ついで, 残りのセルには水 をそれぞれ $3 \mathrm{~m} l$ ずつ入れ, 対照側のこのセルには塩化マンガン (II) $\left(0.1 \mathrm{mmol} \cdot \mathrm{dm}^{-3}\right)$ を加えてかきまぜた。一方, 試料側の 鎖状アリルニリン酸が入っているセルには塩化マンガン(II)(0.1 $\left.\mathrm{mmol} \cdot \mathrm{dm}^{-3}\right)$ を加光，かきまぜた。かきまぜが終わると同時に分 光器の走査を開始した。得られた紫外線吸収差スペクトルは鎖状 アリルニリン酸と塩化マンガン（II) 溶液を混合した 1 分後のもの である。

\section{3 結果および考察}

\section{1 鎖状アリルニリン酸と二価金属イオンとの反応}

鎖状アリルニリン酸の塩化マンガン(II)による反応を 2.2 に 示した条件下で行なった。各鎖状アリル二リン酸から得られた生 成物の分析結果を表 1 亿示与。GPP からは，環状化合物の生成 が非常に少なく，異性化反応によって生成するリナロオールが主

15) J. A. Pople, M.Gordon, J. Am. Chem. Soc., 89, 4253(1967).

16) A. Imamura, H.Fujita, J. Chem. Phys., 61, 115 (1974).

17) E. Ohsawa, Y. Mochizuki, QUPE Bull., 4, 51(1984).

18) R. Cini, M. C. Burla, A. Nunzi, G.P. Polidori, P. F. Zanazzi, J. Chem. Soc., Dalton Trans., 1984, 2467. 
Table 1 The cyclization of acyclic allylic diphosphates with $\mathrm{Mn}^{2+}$ ion

\begin{tabular}{|c|c|c|c|c|c|c|}
\hline Products ${ }^{a)}$ & \multicolumn{2}{|c|}{ GPP } & \multicolumn{2}{|c|}{ NPP } & \multicolumn{2}{|c|}{$( \pm)-\mathrm{LPP}$} \\
\hline \multicolumn{7}{|l|}{ Cyclic compds } \\
\hline$\alpha$-Terpineol & 1.5 & & 9.1 & & 46. 9 & \\
\hline$\gamma$-Terpinene & 1.2 & & $\operatorname{tr}$ & & 0.1 & \\
\hline Limonene & 2.5 & 5.2 & 10. 7 & 21.7 & 0.2 & 47. \\
\hline Terpinolene & $\operatorname{tr}$. & & 1.9 & & $\operatorname{tr}$ & \\
\hline \multicolumn{7}{|l|}{ Acyclic compds } \\
\hline Linalool & 68.5 & & 51.8 & & $\left.44.6^{b}\right)$ & \\
\hline Nerol & tr. & & $25.1^{b)}$ & & 2.1 & \\
\hline Geraniol $i$ & $24.2^{b)}$ & 70 & tr. & 3.2 & 5.7 & \\
\hline Myrcene & 2.1 & & 1.4 & & 0.4 & \\
\hline
\end{tabular}

a) Expressed as the weight $\%$ of products for the ether extract.

b) Hydrolyzed products.

生成物であった。一方, NPP'の場合には，環状化合物は $20 \%$ 程 度生成し，同時に，異性化反応も進行し，かなりの量のリナロオ ールの生成がみられた。3種の鎖状アリル二リン酸のうち, LPP が環状化合物をもっとも多量に生成した。このさい，環状化合物 としては $\alpha$-テルピネオール[1]が主生成物であった。以上のこ

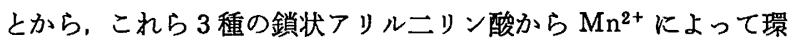
状モノテルペノイドが生成する序列は，LPP $>$ NPP > GPP の順 であることがわかった。この反応性の差異は，鎖状アリルニリン 酸分子が環化するさい, 結合する $\mathrm{C}_{(1)}-\mathrm{C}_{(6)}$ 間の電子状態の違いに よると考えられる。

そこで, GPP，NPPおよびLPPの反応性を分子軌道法(CNDO/2 法）により計算した。その結果，図 1 に示すように, GPP では $\mathrm{C}_{(1)}-\mathrm{C}_{(6)}$ 間の二中心エネルギーは0 となり，二つの炭素間には結 合力が倒かないことがわかった。一方, NPP の場合には $\mathrm{C}_{(1)}-$ $\mathrm{C}_{(6)}$ 間の二中心エネルギーは負の值となり，二つの炭素間は結合 的であることが示された。LPP の場合には $\mathrm{C}_{(1)}-\mathrm{C}_{(6)}$ 間の二中心 エネルギーは大きな負の值を示し，LPP の二つの炭素間は NPP にくらべてより結合しやすいことがわかった。以上の計算結果 は，鎖状アリル二リン酸類の環化反応性が LPP >NPP>GPP の 順になっていることを示している。この反応性の序列は, $\mathrm{Mn}^{2+}$ の作用によって鎖状アリルニリン酸から $\alpha$-テルピネオール [1] が生成する序列と一致している。

さらに, LPP について種々の二価金属イオンを反応させた場 合の $\alpha$-テルピネオール[1]の生成量と生成速度とを調べた。二 価金属イオン種としては， $\mathrm{Mn}^{2+}, \mathrm{Mg}^{2+}, \mathrm{Cu}^{2+}$ および $\mathrm{Fe}^{2+}$ を用 いた。その絬果を表 2 に示す。 $\alpha$ テルピネオール〔1]の生成量
$C_{(1)}-C_{(6)}$ two
center energy

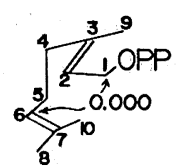

Total energy (A.U.) -225.900

GPP
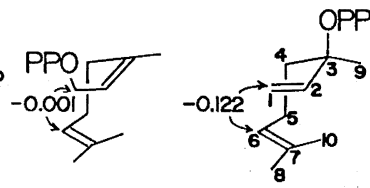

$-225.889$

$-225.945$

NPP
Fig. 1 Total energy of GPP, NPP, and LPP and their two center energy between $C_{(1)}$ and $C_{(6)}$
Table 2 Effect of bivalent metal ion on the formation of $\alpha$-terpineol from LPPa)

\begin{tabular}{lcccl}
\multicolumn{1}{c}{ Metal ion } & $\mathrm{Mn}^{2+}$ & $\mathrm{Mg}^{2+}$ & $\mathrm{Cu}^{2+}$ & $\mathrm{Fe}^{2+}$ \\
\hline$\alpha$-Terpineol $(\%)^{b)}$ & 46.9 & 59.0 & 62.8 & 56.3 \\
$\begin{array}{l}\text { Reaction rate } \\
\left(\times 10^{5} \mathrm{mmol} \cdot \mathrm{dm}^{-3} / \mathrm{s}\right)^{c)}\end{array}$ & 5.11 & 5.19 & 7.08 & 13.10
\end{tabular}

a) A solution of LPP $\left(26.6 \mathrm{mmol} \cdot \mathrm{dm}^{-3}\right)$ were added to the bivalent metal ion $\left(0.6 \mathrm{mmol} \cdot \mathrm{dm}^{-3}\right)$ in 0.1 $\mathrm{mol} \cdot \mathrm{dm}^{-3}$ TES buffer $(\mathrm{pH} 7.0 ; 3 \mathrm{ml})$ and the mixture was incubated at $30^{\circ} \mathrm{C}$ for $6 \mathrm{~h}$.

b) Expressed as the weight $\%$ for the ether extract.

c) Reaction rate was determined by measuring the change in the peak area of GLC.

は金属イオン種による変化はほとんど認められないが，反応速度 は, 配位能の高い二価金属イオンのうちでも， $\mathrm{Cu}^{2+}$ および $\mathrm{Fe}^{2+}$ などのように配位能のより高い二価金属イオン ${ }^{199}$ の場合に，環状 モノテルペノイド生成の速度定数が大きくなることがわかった。

\section{2 二価金属イオンの配位にともなう鎖状アリルニリン酸の}

\section{構造変化}

鎖状アリルニリン酸に二価金属イオンがどのように配位するの かを明らかにするために, $\mathrm{Mn}^{2+}$ が鎖状フリルニリン酸に配位す る際の変化を ${ }^{1} \mathrm{H}-\mathrm{NMR}$ によって解析した。重水溶液中における LPP の ${ }^{1} \mathrm{H}-\mathrm{NMR}$ スペクトルならびそそれらシグナルの㡘属を 因 2 のAに示す。この LPP 重水溶液に $\mathrm{Mn}^{2+}$ を添加すると, 図

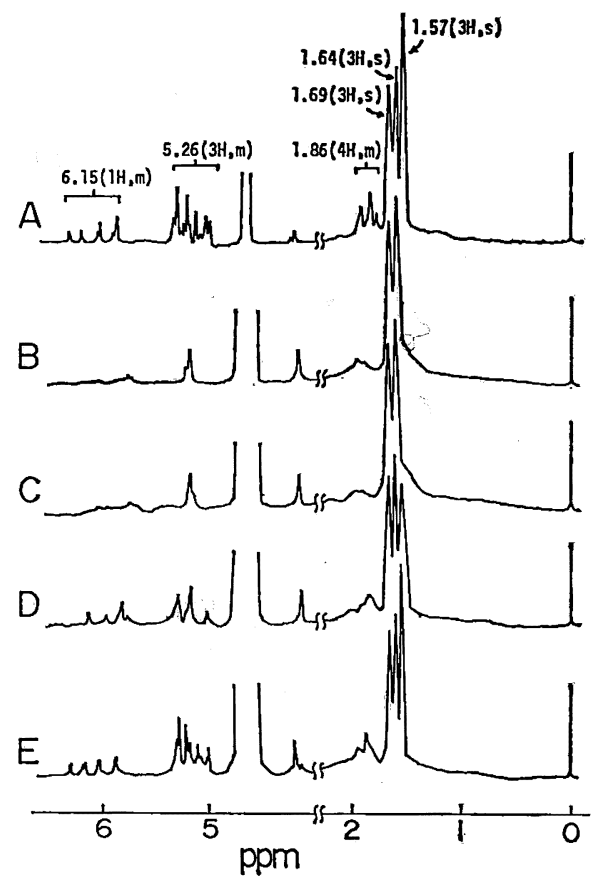

Fig. $2{ }^{1} \mathrm{H}-\mathrm{NMR}$ spectra of LPP $\left(26.6 \mathrm{mmol} \cdot \mathrm{dm}^{-3}\right)$ in the presence of bivalent metal ions $(0.6 \mathrm{mmol}$. $\mathrm{dm}^{-3}$ )

A : no additives, B : $\mathrm{MnCl}_{2} \cdot 4 \mathrm{H}_{2} \mathrm{O}, \mathrm{C}: \mathrm{CuCl}_{2}$, D : $\mathrm{FeCl}_{2} \cdot 6 \mathrm{H}_{2} \mathrm{O}, \mathrm{E}: \mathrm{MgCl}_{2}$

19) Y. Murakami, M. Takagi, J. Phys, Chem., 72, 116 (1968). 
2 のBに示すようにスペクトルの変化が観泚された。これらのス ペクトル変化のらちで高磁場に観測される $1.86 \mathrm{ppm}$ (4- および 5-メチレンブロトン) のシグナルが $\mathrm{Mn}^{2+}$ の添加之同時に広幅化 し、 $1.57 \mathrm{ppm}$ (9-メチルプロトン) のシグナル強度の娍少が観测 された。一オ，低磁場に観測されるシグナルル，陚料中の水の影 整で、 $\mathrm{Mn}^{2+}$ 添加と同時に広幅化し，その変化を钼测することは 困難であった。

LPP に $\mathrm{Mn}^{2+}$ を添加したときに微測された図 2 のBのような スペクトル変化は，二リン酸部分に配位した $\mathrm{Mn}^{2+}$ の常磁性効果

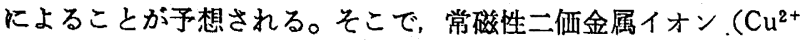
および $\left.\mathrm{Fe}^{2+}\right)$ ならびに反磁性二価金属イオン $\left(\mathrm{Mg}^{2+}\right)$ をそれぞ れ LPP に添加し，それらの ${ }^{1} \mathrm{H}-\mathrm{NMR}$ スペクトルの変化を調べ た。図 2 の C-E にそれらのスペクトル変化を示す。その絬果, $\mathrm{Cu}^{2+}$ と $\mathrm{Fe}^{2+}$ を添加した場合には $\mathrm{Mn}^{2+}$ のときと同様なスペク トル変化が観測されたが、反磁性の $\mathrm{Mg}^{2+}$ を添加した場合には。 常磁性二価金属イオンのときのようなスペクトル变化は観湘され なかった。したがって，LPPに常磁性二洒金属イオンを添加した ときに現われた ${ }^{1} \mathrm{H}-\mathrm{NMR}$ スペクトルの変化は, ニリン酸部分に 配位した二価金属イオンの常磁珄効果によるものであることがわ かった。

NPP については， $\mathrm{Mn}^{2+}$ を添加すると図3に示すようなスぺ クトルの変化が観测された。 $\mathrm{Mn}^{2+}$ の添加と同時に, $2.19 \mathrm{ppm}$ (4- および 5-メチレンプロトン) のシグナルの広幅化と 1.79 ppm (9-メチルプロトン) のシグナル強度の変化が双られた。こ のシクナル強度の変化は, LPP の場合にくらべてかなり小さい。 したがって, $\mathrm{Mn}^{2+}$ は NPP の 9-メチルプロトンに対して影響を 与えにくいような位膡に配位していると考えられる。一方，GPP に $\mathrm{Mn}^{2+}$ を添加した場合には, 図4 に示すようにシグナルの広幅 化も強度栾化も観測されなかった。このことから，NPP の場合 と同様に, $\mathrm{Mn}^{2+}$ は GPP のいずれのメチルプロトンにも影響を 与えにくい位置に配位していると推察される。しかしながら，以 上のような ${ }^{1} \mathrm{H}-\mathrm{NMR}$ のシグナルの変化のみからでは, 二リン酸 部分への $\mathrm{Mn}^{2+}$ の配位の仕方にこれ以上の明確な知見は得られ なかった。そこで，つぎに示すよらに分子軌道法によりリナリル ニリン酸マンガン錯体の構造を解析し，上記の ${ }^{1} \mathrm{H}-\mathrm{NMR}$ スペク トルの測定結果と比較した。

\section{3 リナリルニリン酸マンガン錯体の構造の分子軌道法によ る解析}

LPP の二リン酸部分への $\mathrm{Mn}^{2+}$ の配位により，分子軌道と全 エネルギーがどのように安定するかを，CNDO/2 法を用いて解析 した。まず，図 5 に示すよらに，LPP の $\mathrm{O}_{(4)}$ を中心にして半径 $0.2 \mathrm{~nm}$ の円軌道を考え, この轨道上で, $O_{(7)}$ からも $0.2 \mathrm{~nm} の$ 距離にある位置 $(\mathrm{a})$ を始点として， $\mathrm{O}_{(\mathrm{s})}$ 方向へ $\mathrm{Mn}^{2+}$ を移動させ る。このときに $\mathrm{O}_{(3)}-\mathrm{Mn}^{2+}$ 間の距離の変化にともなう LPP-マン ガン錯体の全エネルギーは，図6亿示すようになった。全ェネル ギーは $\mathrm{O}_{(3)}$ と $\mathrm{Mn}^{2+}$ 間の距離が $0.2 \mathrm{~nm}$ の位置で極小值を与え た。 $\mathrm{O}_{(4)}$ と $\mathrm{Mn}^{2+}$ 間の距離はつねに $0.2 \mathrm{~nm}$ であるから、 $\mathrm{Mn}^{2+}$ が $\mathrm{O}_{(3)}$ と $\mathrm{O}_{(4)}$ のいずれからる等距離にある位置, すなわち図 5 の(b)の位㯰にあるときにもっとも安定な構造をとることがわか った。さらに,このよらな構造をもっている LPP-マンガン錯体 の ${ }^{1} \mathrm{H}-\mathrm{NMR}$ スペクトルにおけるメチルプロトンの強度比は，擬 コンタクトシフトの理論203から，9-位>8-位=10-位の順に変化

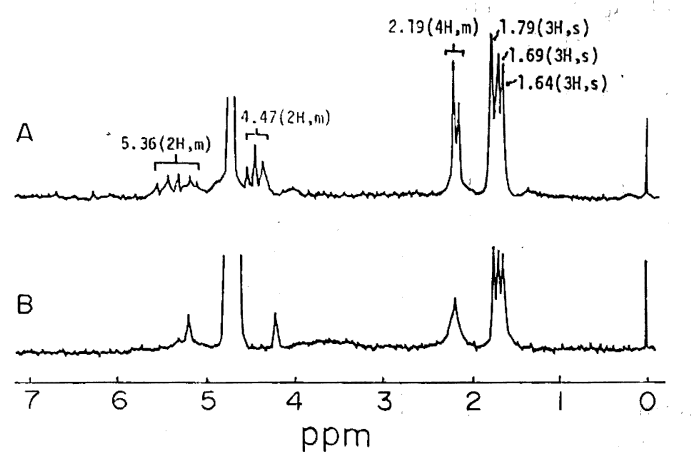

Fig. $3{ }^{1} \mathrm{H}-\mathrm{NMR}$ spectra of NPP $\left(26.6 \mathrm{mmol} \cdot \mathrm{dm}^{-3}\right)$ in the presence of $\mathrm{Mn}^{2+}$ ion $\left(0.6 \mathrm{mmol} \cdot \mathrm{dm}^{-3}\right.$ )

A : no additives, $B: \mathrm{MnCl}_{2} \cdot 4 \mathrm{H}_{2} \mathrm{O}$

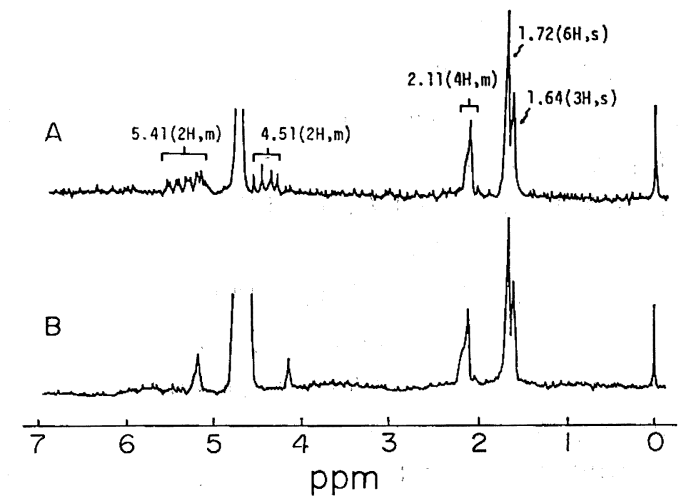

Fig. $4{ }^{1} \mathrm{H}-\mathrm{NMR}$ spectra of GPP $\left(26.6 \mathrm{mmol} \cdot \mathrm{dm}^{-3}\right)$ in the presence of $\mathrm{Mn}^{2+}$ ion $\left(0.6 \mathrm{mmol} \cdot \mathrm{dm}^{-3}\right.$ )

A : no additives, $\mathrm{B}: \mathrm{MnCl}_{2} \cdot 4 \mathrm{H}_{2} \mathrm{O}$

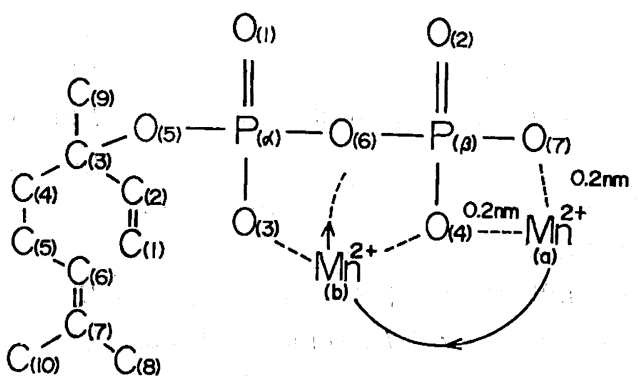

Fig. 5 The possible structure of LPP coordinated with $\mathrm{Mn}^{2+}$ ion

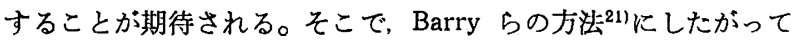
LPP のメチルプロトンの ${ }^{1} \mathrm{H}-\mathrm{NMR}$ スペクトルの変化をシミュ レートした。因 7 にその結果を示す。このメチルプロトンの強度 変化の予测は図 2 の B に示した実験結果ときわめてよく一致し た。以上のことから, $\mathrm{Mn}^{2+}$ は LPP の二リン酸部分に, 分子轨道

20) H. M. McConnell, R. E. Robertson, J. Chem. Phys., 29, 1361(1958).

21) C. D. Barry, A. C. T. North, J. A. Glasel, R. J. P. Williams, A. V. Xavier, Nature, 232, 236(1971). 


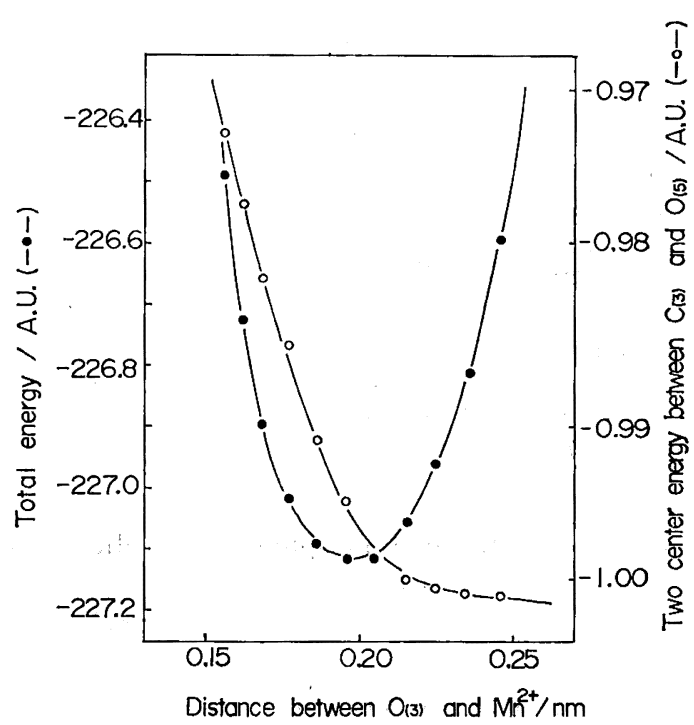

Fig. 6 Total energy of LPP coordinated with $\mathrm{Mn}^{2+}$ and two center energy between $\mathrm{C}_{(3)}$ and $\mathrm{O}_{(5)}$ as a function of the distance between $\mathrm{O}_{(3)}$ and $\mathrm{Mn}^{2+}$ ion

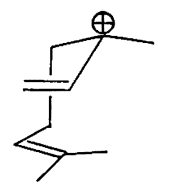

Linalyl cation [2]

法で予測されるようなキレートを形成していることが明らかにな った。また， $\mathrm{C}_{(3)}$ と $\mathrm{O}_{(5)}$ との間の二中心エネルギーは, $\mathrm{Mn}^{2+}$ が $\mathrm{O}_{(3)}$ に近づくにつれて急激に增加することが図6からわかる。し たがって，LPP の二リン酸部分へ $\mathrm{Mn}^{2+}$ がキレート配位するこ とによって LPP の C-O 間の結合が切れやすくなり, 環化反応 に都合のよいリナリルカチオン〔2〕の生成が容易になることが 示された。

さらに，分子軌道法で推定された中間体〔2〕の構造を明らか にするために, $\mathrm{LPP}-\mathrm{Mn}^{2+}$ 系の紫外線吸収差スペクトルを津定 した。その結果, 因 8 に示すように $230 \mathrm{~nm}$ 付近に二重結合の共 役構造の変化に由来すると考えられる差スペクトルが現われた。 しかし，同様な測定を NPP, GPP について行なったが差スペク トルはあらわれなかった。これは，LPP の場合にのみ，二つの二 重結合の間で電子移動が容易に起こり，環化に都合のよい構造を もつリナリルカチオン〔2〕が発生することを示唆している。

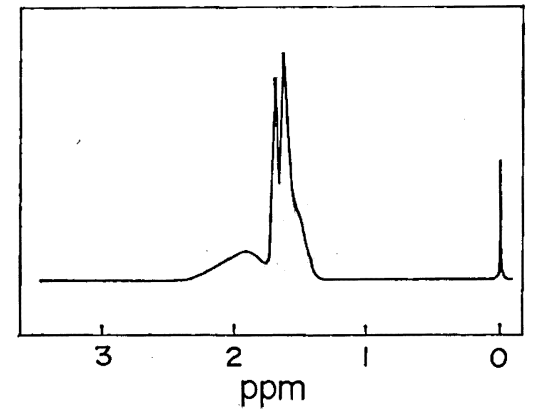

Fig. 7 The simulated ${ }^{1} \mathrm{H}-\mathrm{NMR}$ spectrum of LPP coordinated with $\mathrm{Mn}^{2+}$ ion

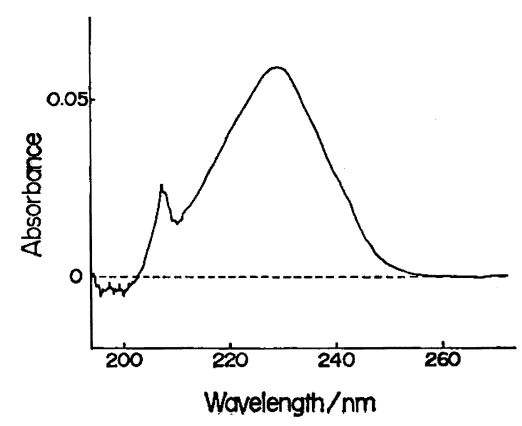

Fig. 8 The UV difference spectrum in the reaction of LPP with $\mathrm{Mn}^{2+}$ ion

\section{4 結論}

以上の結果から, LPP は NPP や GPP よりも二価金属イオン の存在下で $\alpha$-テルピネオール〔1]などの環状モノテルペノイ ドを多く生成することがわかった。さらに LPP について, 二価 金属イオン種 $\left(\mathrm{Mn}^{2+}, \mathrm{Mg}^{2+}, \mathrm{Cu}^{2+}\right.$ および $\left.\mathrm{Fe}^{2+}\right)$ を変えてその 反応性を調べた結果, 配位能の高い二価金属イオンによって環 状モノテルペノイドがより速く生成することがわかった。 ${ }^{1} \mathrm{H}-$ NMR の結果は LPP の三リン酸部分に二価金属イオンがキレー ト配位していることを示した。したがって、二価金属イオンは二 リン酸部分とキレート配位することによって、リナリルニリン酸 中の C-O 結合を弱め，環化反応に都合のよいリナリルカチオン 〔2]を発生しやすくする役割をもっていることがわかった。 なお，この研究は文部省科学研究費一般研究 (A) No. 61430010 によった。分子朹道法の計算にあたり $\mathrm{CNDO} / 2$ 法のブログラム の患与と助言をいたたいた本学理学部今村 詮教授ならびに大作 勝博士に感謝する。計算にさいしては, 広島大学情報処理センタ ーの HITAC M-200 H を用いた。 


\title{
Special Articles on \\ Coordination Chemistry of Biologically Important Substances
}

\section{Biosynthesis of Cyclic Monoterpenoids - The Role of Bivalent Metal Cations in the Cyclization of Acyclic Allylic Diphosphates ${ }^{\dagger}$}

\author{
Takayuki Suga*, Shunsuke Izumı and Yoshikazu HiRaga \\ Department of Chemistry, Faculty of Science, Hiroshima University; \\ Higashisenda-machi, Naka-ku, Hiroshima-shi 730 Japan
}

The role of bivalent metal cations in the cyclization of acyclic allylic diphosphates to cyclic monoterpenoids was investigated. The reaction of linalyl diphosphate (LPP) with the bivalent metal ions was found to give much more amount of $\alpha$-terpineol than in the cases of neryl diphosphate (NPP) and geranyl diphosphate (GPP) with the metal ions. The reaction of these allylic diphosphates with $\mathrm{Mn}^{2+}$ ion was traced by the ${ }^{1} \mathrm{H}-\mathrm{NMR}$ spectroscopy, and a change in the intensity of the C-9 methyl proton signal was observed only in the case of LPP. This change was found to result from the coordination of $\mathrm{Mn}^{2+}$ ion with the diphosphate moiety. The structure analysis of LPP chelated with $\mathrm{Mn}^{2+}$ ion was carried out by $\mathrm{CNDO} / 2$ calculation, and the analysis indicated that the C-O bond of LPP is weakened by the chelation of $\mathrm{Mn}^{2+}$ ion.

It was thus established that the bivalent metal cation chelates the diphosphate moiety of LPP and plays a role in the production of linalyl cation by pulling out the diphosphate moiety.

$\dagger$ The Biosynthesis of Isoprenoids in Higher Plants. V. 